\title{
SEROPREVALANCE OF TOXOPLASMA GONDII ANTIBODIES IN ANTENATAL POPULATION OF TRAKYA REGION
}

\author{
Fusun G. VAROL, N. Cenk SAYIN, Seyit SOYSUREN \\ Department of Gynecology and Obstetric, Faculty of Medicine, Trakya University, Edirne, Turkey
}

\begin{abstract}
SUMMARY
Objective: To investigate the distribution of toxoplasma gondii antibodies retrospectively among the first trimestr antenatal population in Trakya region.

Material and methods: This study retrospectively analyzes seroprevalance of toxoplasma gondii IgM and IgG antibodies in the sera of 1646 first trimester pregnancies attended to the Obstetrics \& gynecology Antenatal Care Unit in Trakya University, Faculty of Medicine between January 2000 and June 2009. For this purpose IgM, IgG and if necessary, IgG avidity results were evaluated. Besides, hepatitis B surface antigen (HBsAg), human inmmunodeficieny virus type 1 and 2 antibodies (Anti HIV), cytomegalovirus (AntiCMV) IgG and IgM antibodies, hepatitis $C$ antibody (AntiHCV), rubella (antirubella) IgM and IgG antibodies and "venereal disease research laboratory" (VDRL) results evaluated in the same period were also investigated.

Results: Although the status of seroprevalance is not known in 313 (19\%) women, 876 pregnant women (65.71\%) were IgG and IgM seronegative, 426 (31.95\%) were IgG seropositivite, 13 (0.97\%) were IgM positivite and 18 (1.35\%) were both IgG and IgM seropositivite. On the other hand, 13 of 18 patients with both $\operatorname{IgG}$ and $\operatorname{IgM}$ seropositivity showed high avidity but avidity could not be evaluated in 4 patients. HBsAg positivity was found in 3\% (47/1526), AntiHCV positivity in 0.8\% (12/1474), VDRL in 0.4\% (5/1056), rubella IgM antibody in 0.7\% (9/1254), rubella IgG antibody in 76.6\% (940/1227), according to the other serologic tests. AntiCMV IgM antibody was positive in 17 (17/1284, 1.3\%) and IgG was positive in 1027 (1027/1279, 80.3\%) patients. Conclusion: As well as toxoplasma exposure rate in the pregnant women from Trakya region of Turkey is high (\%30), nearly half of first trimester women were found seronegative. Screening during the first trimester would be appropriate, particularly for women who are under risk of infection.
\end{abstract}

Key words: pregnancy, toxoplasmosis

Journal of Turkish Society of Obstetrics and Gynecology, (J Turk Soc Obstet Gynecol), 2011; Vol: 8 Issue: 2 Pages: 93- 9

\section{ÖZET}

\section{TRAKYA YÖRESINDE ANTENATAL BAKIM ALAN GEBELERDE TOXOPLASMA GONDII ANTIKOR SEROPREVALANSI}

\begin{abstract}
Amaç: Trakya Bölgesinde antenatal bakım için başvuran ilk trimester gebeliklerinde toxoplasma gondii antikor seroprevalansinin retrospektif olarak incelenmesi

Gereç ve yöntemler: Bu çalışmada 2000-2009 yılları arasında Trakya Üniversitesi Tıp Fakültesi Kadın Doğum Antenatal Polikliniğine ilk trimesterde başvuran toplam 1646 gebe serumunda toxoplasma gondii IgG ve IgM antikor sonuçları retrospektif olarak değerlendirilmiştir. Bu amaçla $\operatorname{IgM}$, IgG ve gerekli durumlarda IgG aviditesi sonuçlarına bakılmıştır. Ayrıca bu dönemde bakılan hepatit B yüzey antijeni (HBsAg), “human inmmunodeficieny virus” tip 1
\end{abstract}

Address for Correspondence: Fusun G. Varol. Trakya Üniversitesi Tıp Fakültesi, Kadın Hastalıkları ve Doğum Anabilim Dalı, Edirne, Turkey Phone: +90 (284) $2357641-4302$

e-mail: fgvarol@yahoo.com

Received: 08 June 2010, revised: 26 November 2010, accepted: 08 December 2010, online publication: 14 March 2011 
ve 2 antikoru (Anti HIV), sitomegalovirüs antikoru (AntiCMV) IgM ve IgG, hepatit C antikoru (AntiHCV), rubella antikoru (Antirubella) IgG ve IgM ve VDRL ("venereal disease research laboratory") test sonuçlarl da incelendi. Bulgular: Gebelerin 313'de (\%19) antikor titresi bilinmemekle beraber, 876'da (\%65.71) IgG ve IgM seronegatifliği, 426'da (\%31.95) IgG seropozitifliği, 13'de (\%0.97) ise IgM seropozitifliği, 18'de (\%1.35) IgG ve IgM seropozitifliği görülmüsşür. Diğer taraftan avidite testi yapılan IgM ve IgG seropozitifliği saptanan 18 hastanin 13 'ünde yüksek avidite bulundu ancak dördüne avidite bakalamadı. Diğer serolojik testlerden ise HBsAg pozitifliği \%3 (47/1526), AntiHCV pozitifliği $\% 0.8$ (12/1474), VDRL \%0.4 (5/1056), rubella IgM antikoru \%0.7 (9/1254), rubella IgG antikoru \%76.6 (940/1227) oraninda pozitif izlendi. AntiCMV IgM 17 (17/1284, \%1.3), IgG ise 1027 (1027/1279, \%80.3) olguda pozitif bulundu. Sonuç: Trakya Bölgesindeki gebelerde toksoplasma ile gebelik öncesi karşılaşma oranı yüksek (\%30) olmakla birlikte ilk trimesterdeki gebe kadınların yarısı seronegatiftir. Gebeliğin ilk trimesterinde toksoplasma taraması yapılması özellikle risk altındaki kişilerde uygun olacaktır.

Anahtar kelimeler: gebelik, toksoplasmosis

Türk Jinekoloji ve Obstetrik Derneği Dergisi, (J Turk Soc Obstet Gynecol), 2011; Cilt: 8 Sayl: 2 Sayfa: 93-9

\section{INTRODUCTION}

Negative results of toxoplasma gondii infection during pregnancy on fetus and neonate are known. Though it is preventable with various public health measures, diverse clinical manifestations may be seen in $35-40 \%$ of the adult population. Infection may be transmitted to humans in cyst form from meat products, via blood transfusion, during organ transplantation and placentally. Highest level of placental transmission is in the third trimester and it can reach to $80 \%$ at the end of pregnancy while lowest level of transmission is seen in the first trimester. In nearly $30-50 \%$ of the infected pregnants who aren't treated, various complications occur depending on the period when infection begins. Abortus, fetal death, neurological or ocular damage may develop. Although sensory losses such as hearing loss and loss of vision;, mental and psychomotor retardation; hematologic problems; hepatosplenomegaly or death may be seen in fetus, most are born asymptomatically. Systematic education and serologic researches during pregnancy is the most reliable approach for now in early diagnosis, treatment and prevention of toxoplasma infection. Proper treatment in the early stages of neonate's life improves the clinical results considerably ${ }^{(1-3)}$.

With this retrospective data evaluation, toxoplasma gondii factor exposure among first trimester pregnants who attended to Obstetrics \& Gynecology Department Antenatal Care unit in Trakya University School of Medicine was researched and for this purpose IgM, IgG and if necessary, IgG avidity results were evaluated. Besides, evaluations of this region were compared with those of other regions of Turkey.

\section{MATERIAL AND METHODS}

In our study, 1646 pregnant women between the ages of 16 and 50 who attended Obstetrics \& Gynecology Department Antenatal Care unit in Trakya University School of Medicine in the first trimester between the years 2000-2009 were enrolled. Demograpfic characteristics and serological test results were recorded from the polyclinic follow-up cards of patients. Apart from the routine tests (hemogram, blood group, urine analysis etc.), toxoplasma gondii IgG and IgM antibody tests were also done for the patients who attended to antenatal care. Besides, hepatitis B surface antigen (HBsAg), "human inmmunodeficieny virus" type 1 and 2 antibodies (Anti HIV), cytomegalovirus IgG and IgM antibodies (AntiCMV), hepatitis C antibody (AntiHCV), rubella (antirubella) IgM and IgG antibodies and VDRL ("venereal disease research laboratory") results were evaluated retrospectively. Toxoplasma gondii IgG avidity was tested by indirect fluorescent antibody test (IFAT) method for toxoplasma gondii IgG and IgM positive patients. No additional test was done for cases in which only IgM (+) was found, in some cases IgM test was repeated. Besides, in $18 \mathrm{IgM}$ and $\operatorname{IgG}$ positive cases, neonatal records of infants were investigated. For all the toxoplasma, antirubella and anti CMV IgG and IgM tests (Axsym, Abbott Lab., IL, USA); for HbsAg, AntiHIV and AntiHCV (Vitros, Ortho-Clinical Diagnosis, Johnson\&Johnson CO., Brasil) and for VDRL (Immuntrep VDRL, Omega Diagnostics, UK) kits were used. Analysis of all blood samples was performed using Macro ELISA method and Abbott Axysm, USA and Vitros Immunodiagnostic ECIQ, UK 
devices in Trakya University School of Medicine Microbiology Laboratory whereas VDRL was performed manually.

Fetal anomaly (congenital hip dislocation, pes equinovarus, digital anomaly of the hand) in four of our cases, molar pregnancy in 2 cases and ectopic pregnancy anamnesis in 4 cases were present in their previous pregnancies. In addition, nephrological problems (pyelonephritis, nephrolithiasis, polycystic kidney, glomerulonephritis, nephrotic syndrome) in 8 , epilepsy in 5, hematological diseases (thalassemia minor, essential thrombocytopenia) in 27 , thyroid diseases (hypo-, hyperthyroidism, goiter, Hashimoto) in 51, cardiac (arrhythmia, congenital cardiac disease, mitral prolapse) in 7 , rheumatic or skin diseases (Behcet, lupus, FMF, ankylosing spondylitis, vitiligo, eczema, psoriasis) in 10, psychiatric problems in 6 , gastrointestinal diseases (gastritis, hemorrhoid, cholelithiasis, spastic colon) in 10 and Type I diabetes history were present in 2 pregnant women. 2 patients became pregnant after primary infertility whereas one patient got pregnant with ovulation induction. Of the 19 pregnant women who has a respiratory disease history, chronic sinusitis or bronchitis anamnesis of 3 , asthma anamnesis of 12 and tuberculosis anamnesis of 2 were taken.

\section{RESULTS}

The mean age of 1646 cases was calculated as $27.8 \pm 2.12$. Among the pregnant women 1330 (79\%) stated that they are housewives while 346 (21\%) are working. Numbers of median gravidity (minimum-maximum), parity and abortus of our cases are indicated in Table I. HIV tests done in this period were found negative in all the pregnant women $(\mathrm{n}=1510)$.

For 313 (\%19) of the pregnant women toxoplasma tests weren't done. On the other hand, of $1333(\% 81)$ patients who had test results; for $876(\% 65.71)$ IgG and IgM seronegativity; for 426 (\%31.95) IgG

Table I: Distribution of other serological tests by demographic characteristics and toxoplasma serological results of the cases

\begin{tabular}{|c|c|c|c|c|c|c|}
\hline & $\begin{array}{l}\operatorname{IgM}(+) \\
\operatorname{IgG}(+) \\
(n=18)\end{array}$ & $\begin{array}{l}\operatorname{IgM}(+) \\
\operatorname{IgG}(-) \\
(n=13)\end{array}$ & $\begin{array}{l}\operatorname{IgM}(-) \\
\operatorname{IgG}(+) \\
(n=426)\end{array}$ & $\begin{array}{l}\operatorname{IgM(-)} \\
\operatorname{IgG(-)} \\
(\mathrm{n}=876)\end{array}$ & $\begin{array}{l}\text { Indefinite } \\
\text { Serology } \\
(n=313)\end{array}$ & $\begin{array}{l}\text { Total } \\
(n=1646)\end{array}$ \\
\hline Age (years, mean $\pm \mathrm{SD}$ ) & $27.2 \pm 1.41$ & $25.9 \pm 6.36$ & $28.5 \pm 1.41$ & $27.3 \pm 0.71$ & $28.6 \pm 3.54$ & $27.8 \pm 2.12$ \\
\hline Working & $3(\% 16.6)$ & $3(\% 23)$ & $94(\% 22)$ & $194(\% 22.1)$ & $52(\% 16.6)$ & $346(\% 21)$ \\
\hline Gravidity [median (min.-max.)] & $2(1-5)$ & $1(1-3)$ & $2(1-7)$ & $1(1-7)$ & $2(1-8)$ & $2(1-8)$ \\
\hline Parity [median (min.-max.)] & $1(0-4)$ & $0(0-2)$ & $1(0-4)$ & $0(0-5)$ & $1(0-5)$ & $0(0-5)$ \\
\hline Abortus [median (min.-max.)] & $0(0-1)$ & $0(0-1)$ & $0(0-4)$ & $0(0-4)$ & $0(0-4)$ & $0(0-4)$ \\
\hline HBsAg $(n=1526)$ & 1 & 0 & 14 & 23 & 9 & $47(\% 3)^{*}$ \\
\hline AntiHCV (n=1474) & 0 & 0 & 3 & 6 & 3 & $12(\% 0.8)^{*}$ \\
\hline VDRL $(n=1056)$ & 0 & 0 & 4 & 1 & 0 & $5(\% 0.4)^{*}$ \\
\hline Antirubella Ig M ( $\mathrm{n}=1254)$ & 2 & 0 & 2 & 5 & 0 & $9(\% 0.7)^{*}$ \\
\hline Antirubella Ig G ( $\mathrm{n}=1227)$ & 14 & 6 & 322 & 573 & 25 & $940(\% 76.6)^{*}$ \\
\hline AntiCMV Ig M ( $\mathrm{n}=1284)$ & 0 & 0 & 5 & 12 & 0 & $17(\% 1.3)^{*}$ \\
\hline AntiCMV Ig G (n=1279) & 12 & 8 & 355 & 627 & 25 & $1027(\% 80.3)^{*}$ \\
\hline
\end{tabular}

*: Percentages were calculated according to the number of patients who had serological tests.

IgM: Immunoglobulin M, IgG: Immunoglobulin G, HBsAg: Hepatitis B surface antigen, AntiHCV: Hepatitis C antibody, VDRL: "Venereal disease research laboratory", AntiCMV: Cytomegalovirus antibody.

Table II: Distribution of toxoplasma serological results in pregnant woman by years.

\begin{tabular}{|c|c|c|c|c|c|c|}
\hline & $\begin{array}{l}\text { IgG(-) } \\
\operatorname{IgM(-)}\end{array}$ & $\begin{array}{l}\operatorname{IgG}(+) \\
\operatorname{IgM(-)}\end{array}$ & $\begin{array}{l}\operatorname{IgG(-)} \\
\operatorname{IgM(+)}\end{array}$ & $\begin{array}{l}\operatorname{IgG}(+) \\
\operatorname{IgM(+)}\end{array}$ & $\begin{array}{l}\text { Indefinite } \\
\text { Serology }\end{array}$ & Total \\
\hline 2000 & 8 & 1 & 0 & 0 & 2 & 11 \\
\hline 2001 & 7 & 1 & 0 & 0 & 1 & 9 \\
\hline 2002 & 74 & 45 & 0 & 1 & 78 & 198 \\
\hline 2003 & 203 & 94 & 3 & 2 & 84 & 386 \\
\hline 2004 & 176 & 87 & 5 & 4 & 59 & 331 \\
\hline 2005 & 145 & 52 & 5 & 6 & 17 & 225 \\
\hline 2006 & 81 & 33 & 0 & 2 & 9 & 125 \\
\hline 2007 & 59 & 41 & 0 & 2 & 30 & 132 \\
\hline 2008 & 102 & 60 & 0 & 1 & 28 & 191 \\
\hline 2009 & 21 & 12 & 0 & 0 & 5 & 38 \\
\hline Total & 876 & 426 & 13 & 18 & 313 & 1646 \\
\hline
\end{tabular}

IgM: Immunoglobulin M, IgG: Immunoglobulin G. 
seropositivity; and for 13 (\%0.97) IgM seropositivity (seronegativity was found in repeated controls of 4 pregnant women) were determined. $\operatorname{IgG}$ and $\operatorname{IgM}$ seropositivity was seen in eighteen pregnant women $(1.35 \%)$. Distribution of test results by years in our cases was also analyzed (Table II).

Of the 18 patients whose toxoplasma $\operatorname{IgG}$ and $\operatorname{IgM}$ were found positive, $\operatorname{IgM}$ of 1 patient was negative in control, 13 patients showed high IgG avidity and avidity of 4 patients couldn't be checked because they weren't reached (Table III).

Table III: Distribution of "Avidity" test results in real seropositive patients

\begin{tabular}{lllll}
\hline & $\begin{array}{l}\text { High } \\
\text { Avidity }\end{array}$ & $\begin{array}{l}\text { Low } \\
\text { Avidity }\end{array}$ & $\begin{array}{l}\text { Control } \\
\text { Negative }\end{array}$ & $\begin{array}{l}\text { Avidity } \\
\text { not checked }\end{array}$ \\
\hline $\begin{array}{l}\operatorname{IgG}(+) \\
\operatorname{IgM}(+) \\
\mathrm{n}=18\end{array}$ & 13 & 0 & 1 & 4 \\
\hline
\end{tabular}

IgM: Immunoglobulin M, IgG: Immunoglobulin G.

Among the other serological tests evaluated HBsAg positivity and AntiHCV positivity were determined in $\% 3(47 / 1526)$ and $\% 0.8(12 / 1474)$ of the patients, respectively. VDRL test, rubella IgM antibody, rubella $\mathrm{IgG}$ antibody were seen positive at the percentages of $0.4 \%(5 / 1056), 0.7 \%(9 / 1254), 76.6 \%$ $(940 / 1227)$ respectively. Of the 9 people who had rubella IgM positivity, coexisting rubella IgG positivity was seen in only 3 . Similarly, number of antiCMV IgM positive cases was 17 (17/1284, 1.3\%) and IgG positive was 1027 (1027/1279, \%80.3). AntiCMV IgG (+) was found in 14 of the AntiCMV IgM positive patients.

No pathology was found in the early and late neonatal periods of the infants of pregnant women who were found toxoplasma IgM seropositive during their followup in our clinic.

\section{DISCUSSION}

Congenital toxoplasmosis generally occurs concomitantly with primary infection. Very rarely, in the course of immunodeficiency, AIDS and corticosteroid usage, clinical manifestation appears as a result of reactivation of the chronic disease. Clinical manifestation of the disease is generally seen with non-specific symptoms such as fatigue, medium fever and vision problems related to chorioretinitis. Maternal infection is transmitted to fetus by vertical transmission in direct proportion to the week of pregnancy. While congenital toxoplasmosis clinic that occurs in the early weeks of pregnancy progresses slowly, possibility of sequel increases. But disease causes mortality and morbidity in inverse proportion to pregnancy week ${ }^{(1)}$.

4 groups are found regarding serology in the case of infection during pregnancy. First group naive to toxoplasma antigen with negative $\operatorname{IgM}$ and $\operatorname{IgG}$ is at risk regarding toxoplasma during pregnancy. Public health measures are fundemental for these people who are in risk in case they are infected with toxoplasma infection during pregnancy. If the person is living in a risky society in terms of toxoplasmosis, in order to see the seroconversion that may occur during pregnancy, it might be necessary to repeat the tests. $65.71 \%$ of our patient group was found seronegative in terms of toxoplasmosis and is at risk of having toxoplasmosis during pregnancy but having toxoplasmosis tests in each trimester brings costs. Therefore, it was not reccomended to take these tests in each trimester. But for the cases that are suspicious regarding infection in ultrasonography, repeating the toxoplasmosis tests for early diagnosis and treatment may be recommended.

Second group is the one that is toxoplasma $\operatorname{IgG}(+)$ $\operatorname{IgM}(-)$ in the first trimester and regarded as immune. This group has the lowest risk in terms of congenital toxoplasmosis but there may be reactivation of chronic infections in the patients whose immune system is impaired. Besides, it is recommended that these tests are obtained in the first trimester and serum samples taken are kept during pregnancy ${ }^{(1)}$. In the research we did in Trakya region, ratio of people in this group in the pregnant society of reproductive age was $31.95 \%$. Gunes et al. found this ratio for 18-49 age group in Isparta and its surrounding high, approximately $75.6 \%(4)$. In various studies, it was determined that depending on age $20-60 \%$ of our society, is infected with toxoplasma gondii(4-11). While seropositivity ratio in Urfa region was given in a wide range between $21 \%$ and $59 \%$; it was determined as $41.9 \%$ in Erzurum region, 36\% in Van region, 39.6\% in Malatya region, $31 \%$ in Ankara according to 2 different studies, 30.7\% in Afyon region, 30.1\% in Aydin region and 43\% in İstanbul(12-21). According to the toxoplasma seroprevalance study done by Saracoglu and Sahin 
among 231 pregnant women in Ankara region: IgM and $\mathrm{IgG}(-)$ was determined as 58.4\%; Ig M (-) IgG $(+)$ as $38.1 \%$; $\operatorname{IgM}(+)$ and $\operatorname{IgG}(+)$ as $3.46 \%$ and $\operatorname{IgM}$ $(+) \operatorname{IgG}(-)$ as $1.48 \%\left({ }^{(9)}\right.$. Similarly, in a study conducted in Kocaeli where 1972 pregnant women were scanned, $\operatorname{IgG}(+)$ was found $48.3 \%$, only $\operatorname{IgM}(+)$ was $0.4 \%$, $\operatorname{IgM}$ and $\operatorname{IgG}(+)$ was $1.6^{(22)} \%$. Parallel to the previous studies, in Hatay and its surroundings, toxoplasma $\operatorname{IgG}(+)$ and $\operatorname{IgM}(+)$ were found $52.1 \%$ and $0.54 \%$ respectively ${ }^{(23)}$. In the years 2003-2004 in İzmir among a woman population of 1274 (82\%), 25\% IgG seropositivity, $0.7 \%$ IgM seropositivity, 2.64\% IgG and $\operatorname{IgM}$ seropositivity were determined(10). These numbers are similar to the ratios we found in our study. It is reported that $20-80 \%$ seropositivity was found in America, Europe and Asia $(11,24)$.

Third group is the group that is toxoplasma $\operatorname{IgM}(+)$ and still found to be $\operatorname{IgG}(-)$ during pregnancy. In this group seroconversion may be seen by repeating the $\operatorname{IgG} / \operatorname{IgM}$ tests at intervals of 1-3 weeks. If seroconversion has not occured, IgM positivity is not clinically significant ${ }^{(1)}$. These results are followed as the $\operatorname{IgM}(-)$ and $\operatorname{IgG}(-)$ ones. On the other hand, if $\operatorname{IgM}(+) \operatorname{IgG}(+)$ seroconversion has occured, then infection has developed in pregnancy and fetus is at the risk of congenital toxoplasmosis. These cases should be followed in terms of congenital toxoplasmosis for nearly 18 weeks by doing a PCR (polimerase chain reaction) in amniotic fluid with amniocentesis and ultrasound. In the studies conducted in Europe and America, it was reported that infants with congenital toxoplasmosis were born at the ratios of $1 / 1000-0.1 / 1000^{(25-27)}$. It has been determined that 500-5000 neonates are infected in America each year ${ }^{(28)}$. In the countries like France where toxoplasma is commonly seen, congenital toxoplasma prevalance has been determined as 3.3 in 10.000 live births whereas symptomatic infection has been determined as $0.34 / 10.000^{(2)}$. It is alleged that "Toll-like" receptors, adhesins, cytokines, chemokines or chemokines receptors, immunoglobulines or gene polymorphism of Fc receptors may be responsible for the tendency of toxoplasma towards vertical, inherited, abortus and fetal infection ${ }^{(3)}$

In the forth group, IgG positivity accompany with $\operatorname{IgM}$ positivity. But there is a problem about when $\mathrm{IgG}$ positivity occurs. In this case $\mathrm{IgG}$ avidity tests are demanded. 12-16 weeks after the infection, IgG antibodies showing high avidity develop. So, if $\mathrm{IgG}$ showing high avidity has developed, then infection must have occurred at least 12-16 weeks ago and there is no congenital toxoplasmosis risk ${ }^{(1)}$. Of the 18 cases in which $\operatorname{IgM}$ and $\operatorname{IgG}(+)$ were determined in our study, avidity was determined as high in all 13 cases for which avidity test was done and they indicated the old infection. In a research made in Brasil, another country with a high toxoplasma seropositivity, the fact that avidity test presented the new infection at a ratio of $28 \%$ pointed out the significance of national screening (29).

Toxoplasmosis screening is stil an up-to-date and controversial subject about prenatal care. Nowadays, in our country toxoplasmosis screening is not done at all or is performed by unstandardized methods $(30)$. Systematic serological screening in terms of toxoplasma antibodies is required by law in countries like France and Austria. While there is no such obligation in our country, it may be recommended in the first trimester in places like Southeastern and Eastern Anatolia where raw meat is consumed. Reevaluation of the toxoplasma $\operatorname{IgM}(+)$ and $\operatorname{IgG}(+)$ samples in laboratories that are regarded as reference may be appropriate ${ }^{(1)}$. Serological screenings should be obtained in the first trimester as far as possible. Toxoplasma $\operatorname{IgG}, \operatorname{IgM}$ and $\mathrm{IgG}$ avidity tests cost below 30TL dating from 2008.

In our country frequency of hepatitis B surface antigen was researched among 5366 pregnant women and positive results at the ratio of $4.2 \%$ were found ${ }^{(31)}$. HBsAg ratio in our region was also found as 3\%, compatible with this number. Although VDRL is a diagnosis test for syphilis and its seroactivity was stated as $3-18 \%$ among the pregnant women in African countries, in more recent studies VDRL seroreactivity has been found in lower ratios as $0.98 \%(32,33)$. In our society, on the other hand, as expected from these countries, it has been determined in lower ratios as $0.4 \%$. On the west of our country, antirubella IgG positivity has been determined as $94.3-96.1 \%$, IgM positivity as 0.2-1.7\%, antiCMV $\operatorname{IgG}(+)$ as 96.4-97.3\%, $\operatorname{IgM}(+)$ 0.71\%(22,34). In Middle Anatolia, antirubella IgG positivity has been found as $96.2 \%$ (35), in Hatay and its surroundings as $95 \%$, $\operatorname{IgM}(+)$ as $0.54 \%$; antiCMV $\operatorname{IgG}$ $(+)$ as $94.9 \%$, $\operatorname{IgM}(+)$ as $0.4 \%(23)$. Rubella $\operatorname{IgG}$ seroprevalance was determined at the ratio of $93.1 \%$ among school-age children in Edirne and its surroundings and it was calculated that only $6.9 \%$ of the adolescents may be at risk during pregnancy ${ }^{(36)}$. Rubella $\operatorname{IgG}$ 
seroprevalance was determined as \%93.8 in Malatya and its surroundings ${ }^{(37)}$. On the other hand, in a research made in Mersin, rubella seroprevalance was determined as $55 \%$, as $92.5 \%$ in Adana and as $82.1 \%$ in Ankara ${ }^{38}$ 40). As is seen, even in the regions that are close to each other these ratios don't show a homogeneous distribution. Results that are similar to these stated serological results in our country have been found in our research.

Consequently, incidence of toxoplasmosis before pregnancy in Trakya region is about 30\%. About 65\% of the pregnant women are seronegative and toxoplasmosis screening may be appropriate. In addition to this, numbers are not clear about seroconversion of acute maternal toxoplasmosis in pregnancy and polycentric wide screening programs and studies that will represent all Turkish society are needed.

\section{REFERENCES}

1. Montoya JG, Remington JS. Management of toxoplasmosis gondii infection during pregnancy. Clin Infect Dis 2008; 15; 47(4): 554- 66.

2. Villena I, Ancelle T, Delmas C, Garcia P, Brezin AP, Thulliez P, Wallon M, King L, Goulet V; Toxosurv network and National Reference Centre for Toxoplasmosis. Congenital toxoplasmosis in France in 2007: first results from a national surveillance system. Euro Surveill 2010; 15(25). pii: 19600

3. Ortiz-Alegría LB, Caballero-Ortega H, Cañedo-Solares I, Rico-Torres CP, Sahagún-Ruiz A, Medina-Escutia ME, Correa D. Congenital toxoplasmosis: candidate host immune genes relevant for vertical transmission and pathogenesis. Genes Immun 2010; 11(5): 363- 73 .

4. Güneş H, Kaya S, Çetin ES, Taş Tekin, Demirci M. Reproduktif çağdaki kadınlarda toksoplazmozis seroprevalansı. SDÜ Tıp Fakültesi Derg 2008: 15(2): 21- 4.

5. Altıntaş N, Yolasığmaz A, Yazar S, Şakru N, Kitapcıoğlu G. İzmir ve çevresinde yerleşim bölgelerinde yaşayan insanlarda toxoplasma antikorlarının araştırılması. T Parazitol Derg 1998; 22(3): 229- 32

6. Kuman HA, Altıntaş N, Ak M. Ege bölgesinde toksoplasmosis rastlanma sıklığı. T Parazitol Derg 1987; 11: 49- 63.

7. Sütçü A,Tuncer İ, Kuru C, Baykan M. Konya ve çevresi IgG ve IgM prevalans1. T Parazitol Derg 1998; 22(1): 5 - 7.

8. Özbaş G, Afşar İ, Türk M, Gönül B, Orhon M, Türker M. İzmir Atatürk Eğitim ve araştırma hastanesi mikrobiyoloji laboratuvarındaki bir y1llık toxoplasmosis gondii antikor prevalansının araştırılması. İzmir Atatürk Eğitim Hastanesi
Tip Dergisi 2005: 43(1): 33- 6 .

9. Saraçoğlu F, Şahin İ. Gebe populasyonunda toksoplazma prevalansı ve duyarlı gebelerde serolojik dönüşüm oranı. Türkiye Klinikleri J Gynecol Obstet 2001; 11: 326- 8.

10. Türk M, Güngör S, Bayram D, Bilgin N, Er H, Kurultay N, Türker M. İzmir Atatürk Eğitim ve Araştırma Hastanesi'ne bir yılda başvuran toksoplasmosis şüpheli hastaların ELISA yöntemiyle taranması. T Parazitol Derg 2004; 28(2): 80- 2.

11. Enum PA, Stray-Pedersen B, Melby KK, Kapperud G, Whitelaw A, Eskild A, Eng J. Incidence of Toxoplasma gondii infection in 35,940 pregnant women in Norway and pregnancy outcome for infected women. J Clin Microbiol 1998; 36(10): 2900- 6.

12. Aslan G, Altıntaş K, Seyrek A, Kültür N, Güngör Ç. Şanlı Urfa Bölgesindeki kadınlarda Sabin-Feldman testi ile toksoplazma gondii prevalansının saptanması. Erciyes Tıp Dergisi 1998; 20(2): 149- 53.

13. Bayman G, Suay A, Atmaca S, Yayla M. Gebelerde toksoplazma seropozitifliği. T Parazitol Derg 1998; 22(4): 359- 61.

14. Tuncel E, Tuncel Ş, Çelebi S, Sönmez E. Hamile kadınlarda toksoplazma antikorlarının dağılımı. Türk Mikrobiyoloji Cemiyeti Dergisi 1993; 23(1): 36- 9.

15. Efe Ş, Kurdoğlu Z, Korkmaz G. Van yöresindeki gebelerde sitomegalovirüs, rubella ve toksoplazma antikorlarının seroprevalansı. Van Tip Dergisi 2009; 16(1): 6- 9.

16. Bulut Y, Tekerekoğlu MS, Otlu B, Direkel Ş, Durmaz B. Malatya yöresinde dört yıllık sürede toksoplazma antikorlarının dağılımı. T Parazitol Derg 2000; 24(2): 120- 1.

17. Maral I, Aksakal N, Çırak M, Kayıkçıŏ̆lu F, Bumin MA. Sosyal Sigortalar Kurumu Ankara Doğumevi ve Kadın Hastalıkları Eğitim Hastanesi'nde doğum yapmış kentli kadınlarda antitoksoplazma antikorlarının saptanması. Türkiye Klinikleri J Gynecol Obstet 2002; 12(2): 139- 41.

18. Yücel A, Bozdayı G, İmir T. Gazi Üniversitesi'ne başvuran gebe kadınlardaki TORCH seroprevalansı. İnfeksiyon Dergisi 2002; 16(3): 279- 83.

19. Yılmazer M, Altındiş M, Cevrioğlu S, Fenkci V, Aktepe O, Sirthan E. Afyon bölgesinde yaşayan gebe kadınlarda toksoplazma, sitomegalovirus, rubella, hepatit $\mathrm{B}$, hepatit $\mathrm{C}$ seropozitiflik oranları. Kocatepe T1p Dergisi 2004; 5(2): 49- 53.

20. Ertug S, Okyay P, Turkmen M, Yuksel H. Seroprevalence and risk factors for toxoplasma infection among pregnant women in Aydın province, Turkey. BMC Public Health 2005 Jun 15; 5: 66 .

21. Polat E, Aslan M, İsenkul R, Aygün G, Aksın N, Çepni İ, Altaş K. Gebe kadınlarda toxoplasma gondii IgM ve IgG antikorlarının ELISA yöntemi ile araştırılması. T Parazitol Derg 2002; 26(4): 350- 1 .

22. Tamer GS, Dundar D, Caliskan E. Seroprevalence of Toxoplasma 
gondii, rubella and cytomegalovirus among pregnant women in western region of Turkey. Clin Invest Med 2009; 32(1): E43- 7.

23. Ocak S, Zeteroglu S, Ozer C, Dolapcioglu K, Gungoren A. Seroprevalence of Toxoplasma gondii, rubella and cytomegalovirus among pregnant women in southern Turkey. Scand J Infect Dis 2007; 39(3): $231-4$.

24. Aspock H, Pollack A. Prevention of prenatal Toxoplasmosis by serological screening of pregnant women in Austria. Scand J Infect Dis 1992; 84 (suppl): 32- 7.

25. Lynfield R, Guerina NG. Toxoplasmosis. Pediatr Rev 1997 18(3): $75-83$.

26. Foulon W,Naessens A, Volckaert M, Lauwers, Amy JJ. Congenital toxoplasmosis: a prospective survey in Brussels. Br J Obstet Gynaecol 1984; 91(5): 419- 23

27. Lappalainen M, Koskiniemi M, Hiilesmaa V, Ammala P, Teramo K, Koskela P, Lebech M, Raivio KO, Hedman K. Outcome of children after maternal primary toxoplasma infection during pregnancy with emphasis on avidity of specific IgG. Pediatr Infect Dis 1995; 14(5): 354- 61.

28. Bowie WR,King AS, Werker DH, Isaac-Renton JL, Bell A, Eng SB, Marion SA. Outbreak of toxoplasmosis associated with municipal drinking water. The $\mathrm{BC}$ Toxoplasma Invetigation Team. Lancet 1997; 350(9072): 173- 7.

29. Vaz RS, Thomaz-Soccol V, Sumikawa E, Guimarães AT Serological prevalence of Toxoplasma gondii antibodies in pregnant women from Southern Brazil. Parasitol Res 2010; 106(3): 661- 5

30. Duran B, Toktamış A, Erden Ö, Demirel Y, Mamik AB, Çetin M. Doğum öncesi bakımda tartışmalı bir konu: TORCH taraması. CÜ Tıp Fakültesi Dergisi 2002; 24(4): 185- 90

31. Kuru U, Turan O, Kuru N, Saglam Z, Ceylan Y, Nurluoglu
M, Agacfidan A. Prevalence of hepatitis B virus infection in pregnant Turkish women and their families. Eur J Clin Microbiol Infect Dis 1996; 15(3): 248- 51

32. Genç M, Ledger WJ. Syphilis in pregnancy. Sex Transm Infect 2000; 76(2): 73- 9 .

33. Ikeme AC, Okeke TC. The relevance of VDRL as routine test in pregnant women: a critical study. Niger J Clin Pract 2006; 9(1): 65- 7- abstract.

34. Uyar Y, Balci A, Akcali A, Cabar C. Prevalence of rubella and cytomegalovirus antibodies among pregnant women in northern Turkey. New Microbiol 2008; 31(4): 451- 5.

35. Aksakal FN, Maral I, Cirak MY, Aygun R. Rubella seroprevalence among women of childbearing age residing in a rural region: is there a need for rubella vaccination in Turkey? Jpn J Infect Dis. 2007; 60(4): 157-60.

36. Oner N, Vatansever U, Karasalihoglu S, Tatman Otkun M, Ekuklu G, Küçükugurluoglu Y. Rubella seroprevalence among Turkish adolescent girls living in Edirne, Turkey. Turk J Pediatr 2006; 48(4): 288- 93.

37. Pehlivan E, Karaoglu L, Ozen M, Gunes G, Tekerekoglu MS, Genc MF, Egri M, Ercan C. Rubella seroprevalence in an unvaccinated pregnant population in Malatya, Turkey. Public Health 2007; 121(6): 462- 8 .

38. Sasmaz T, Kurt AO, Ozturk C, Bugdayci R, Oner S. Rubella seroprevalence in women in the reproductive period, Mersin, Turkey. Vaccine 2007; 25(5): 912- 7.

39. Karakoc GB, Altintas DU, Kilinc B, Karabay A, Mungan NO, Yilmaz M, Evliyaoglu N. Seroprevalence of rubella in school girls and pregnant women. Eur J Epidemiol 2003; 18(1): 81-4.

40. Güner H, Günay A, Rota S. Seroprevalence of rubella virus in Turkish pregnant women. Int J Gynaecol Obstet 1994; 44(2): 139- 41 . 